A CASE STUDY
Visit us: www.researchjournal.co.in $\frac{\text { Research Journal of Animal Husbandry and Dairy Science }}{\text { Volume 5 | Issue 2| December, 2014|143-147 } \Rightarrow \text { DOI: 10.15740/HAS/RJAHDS/5.2/143-147 }}$

\title{
Applications of high pressure technology for milk processing
}

\author{
S.S. CHOPDE, M.A. DESHMUKH, S.D. KALYANKAR AND S.P. CHANGADE
}

\begin{abstract}
Consumers growing preference for convenient, fresh-like, healthy, palatable, additive-free, high quality and micro-biologically safe food products creates the need to explore beyond the conventional thermal processing techniques. Consequently, a number of non-thermal approaches to food processing have evolved, of which High Pressure Processing (HPP) technology has proven to be very valuable. Attention in HPP applications on milk and dairy products has recently increased. Studies in this arena have shown that pressures between 300 and 600 $\mathrm{MPa}$ are effective to inactivate milk -borne pathogens. In addition to microbial destruction in milk, it has been reported that HPP improves rennet or acid coagulation of milk, ripening of cheese, syneresis and firmness in fermented milk product, ageing of ice cream mix, ripening and fat crystallization of dairy cream, without damaging important natural quality characteristics, such as taste, flavour, vitamins, and nutrients. Present paper highlights the research findings and effects of HPP technology in milk processing.
\end{abstract}

KEY WORDS : High pressure processing, Milk, Technological changes, Microbial destruction

How To CITE THIS PAPER : Chopde, S.S., Deshmukh, M.A., Kalyankar, S.D. and Changade, S.P. (2014). Applications of high pressure technology for milk processing. Res. J. Animal Hus. \& Dairy Sci., 5(2) : 143-147. 